\title{
Calcium ions as bioinspired triggers to reversibly control the coil-to-helix transition in peptide-polymer conjugates $\dagger$
}

\author{
Romina I. Kühnle, ${ }^{a}$ Denis Gebauer ${ }^{b}$ and Hans G. Börner ${ }^{* a}$ \\ Received 8th April 2011, Accepted 24th May 2011 \\ DOI: $10.1039 / \mathrm{c} 1 \mathrm{sm} 05625 \mathrm{e}$
}

Here we present a bioinspired strategy to regulate the most fundamental peptide structure transition from coil-to-helix and elucidate the effect of conjugating the peptide segment to poly (ethylene oxide) (PEO) of different molecular weights. As soft triggers, calcium ions were applied. Regulation of the $\mathrm{Ca}^{2+}$-ion levels via suitable competitive calcium binders resulted in reversing the structural transition (Fig. 1).

To realize a peptide segment, which is capable to perform a reversible coil-to-helix transition, established rules for the design of amphipathic $\alpha$-helices have been applied. ${ }^{13}$ These helices require a specific pattern of polar $(p)$ and hydrophobic $(h)$ amino acids in a $[h p p h p p]_{x}$ sequence. ${ }^{15}$

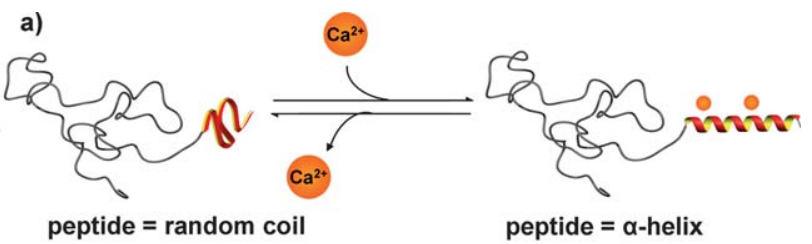
active state by minor changes in $\mathrm{pH}$-value, enzymatic dephosphorylation or the regulation of metal ion levels. ${ }^{10}$ However, these approaches mainly concentrate on the $\beta$-sheet folding motif. The $\alpha$-helical structure motif of peptides occurs as a fundamental structure element in proteins. Homo-poly(amino acid)s adapting $\alpha$-helices have been investigated intensively as part of block-copolymer systems. ${ }^{2,8,11}$ Likewise the assembly behaviour of monodisperse peptides with defined amino acid sequences into $\alpha$-helical coiled-coils was subject of various studies. ${ }^{12,13}$ While metal ion induced coil-tohelix transitions of de novo designed or natural peptides for $\mathrm{Hg}^{2+}$, $\mathrm{Cd}^{2+}, \mathrm{Ni}^{2+}, \mathrm{Cu}^{2+}$ or $\mathrm{Ca}^{2+}$ have been described, ${ }^{14}$ coil-to-helix transitions in peptide-polymer hybrids have so far not been regulated via metal ions.

\footnotetext{
${ }^{a}$ Humboldt-Universität zu Berlin, Department of Chemistry, Laboratory of Organic Synthesis of Functional Systems, Brook-Taylor-Str. 2, D-14289 Berlin, Germany. E-mail: h.boerner@hu-berlin.de; Fax: +49 30 20937500; Tel: +493020937348

${ }^{b}$ Universität Konstanz, Department of Chemistry, Physical Chemistry, Universitätsstr. 10, D-78457 Konstanz, Germany

$\dagger$ Electronic supplementary information (ESI) available: Materials, Synthesis, characterization and calcium binding studies. See DOI: $10.1039 / \mathrm{c} 1 \mathrm{sm} 05625 \mathrm{e}$
}

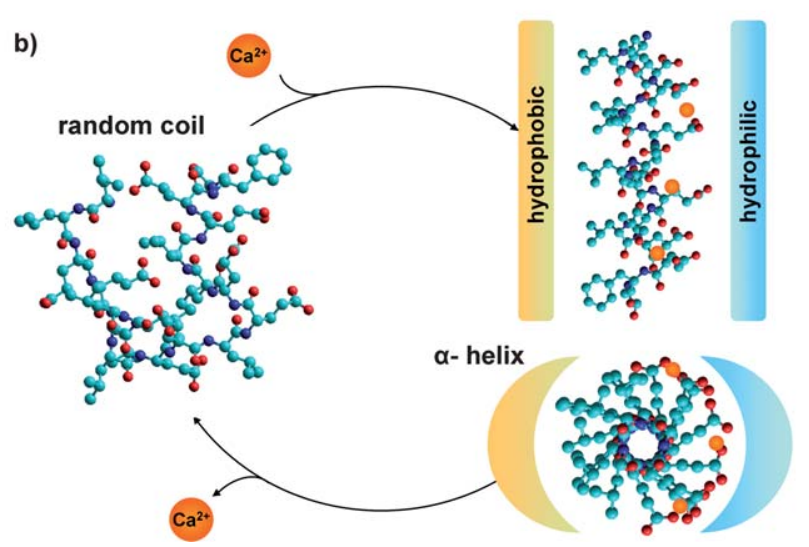

Fig. 1 (a) Schematic representation of the calcium ion induced coil-to helix transition in the peptide-polymer-conjugates. (b) Idealized mechanism for the calcium-ion regulated coil-to-helix transition of the peptide segment. Without calcium ions the peptide segment adopts a statistical chain segment conformation. After calcium ion addition the peptide segment is stabilized as $\alpha$-helix $\left(\mathrm{Ca}^{2+}\right.$ ion binding stoichiometry is idealized). The resulting helix is laterally amphipathic as indicated by the designated hydrophobic and hydrophilic regions. 
To introduce calcium ion sensitivity, glutamic acid (E) was positioned as polar residue and leucine (L) was used as hydrophobic amino acid. The chosen sequence results in a laterally polarized $\alpha$-helix, where the side chains of $L$ are grouped on one side and the carboxy-functionalities of the $\mathrm{E}$ residues are grouped along a polar patch on the other side of the helix (cf. Fig. 1).

To decrease the overall charge of the peptide at neutral $\mathrm{pH}$, the glutamic acid at the fifth position of the pattern was replaced by an additional leucine. Considering the design rules discussed above, a peptide exhibiting the sequence [LEELLEE] $]_{2}$ was proposed. At the $\mathrm{N}$-terminal side another leucine residue was introduced to strengthen hydrophobic interactions and at the C-terminal end para-nitrophenylalanine was added as a spectroscopic marker, followed by glycine as a flexible spacer between the peptide and PEO-block. Conceptionally at $\mathrm{pH} \approx 7$ the propensity for the $\alpha$-helical structure should be strongly reduced. In an $\alpha$-helix the fully deprotonated carboxylates of eight glutamic acid residues being positioned in close proximity, result in strong Coulomb repulsion and hence destabilize the helix.

The peptide was synthesized on a 2-chlorotritylchloride resin, using automated solid-phase peptide synthesis. Liberation of the peptide from the support provides the fully deprotected peptide. The chemical identity was confirmed by means of MALDI-TOF mass spectrometry, ${ }^{1} \mathrm{H} \quad$ NMR and FT-IR spectroscopy (see the ESI + ).

The peptide was readily soluble in $0.17 \mathrm{~mm}$ tris(hydroxymethyl) aminomethane (Tris)/ $\mathrm{HCl}$ buffer $(\mathrm{pH} 8.9)$ at a concentration of $0.17 \mathrm{mg} \mathrm{mL}^{-1}$. Consistent with the design concept, the peptide adopts a statistical chain segment conformation (random coil) prior to the addition of calcium ions (Fig. S4 $\dagger$ ). This was suggested by CD spectroscopy, indicating a characteristic negative Cotton effect at $\lambda=$ $198 \mathrm{~nm}$ (cf. the ESI, Fig. S4†). However, the coil-to-helix transition could be effectively stimulated by the addition of different aliquots of calcium chloride. CD spectroscopy allows us to follow the rapid secondary structure transition. About two minutes after addition of 0.06 eq. $\mathrm{Ca}^{2+}$ per carboxylic acid side chain of the peptide the Cotton effects for an $\alpha$-helical structure were evident $(\lambda=192-195 \mathrm{~nm}(+)$, $208 \mathrm{~nm}(-)$ and $222 \mathrm{~nm}(-))$. The helicity increased on increasing the calcium ion concentration as evident by the ratio of the signal intensity $\theta_{222} \mathrm{~nm} / \theta_{208} \mathrm{~nm}$ approaching the value one (Fig. 3). Moreover, the existence of an isodichroic point in the CD spectra proves the clean structural transition between two distinct secondary structures (Fig. S4†).

To further elucidate the calcium induced coil-to-helix transition, the calcium binding abilities of the peptide were investigated applying calcium ion-titration. ${ }^{16} \mathrm{~A}$ calcium ion solution was titrated to a solution of the peptide at $\mathrm{pH} 8.5$. The $\mathrm{Ca}^{2+}$ ion potential was monitored by means of an ion selective electrode (see the ESI $\dagger$ ). Interestingly, the calcium ion binding capability of the peptide was estimated to be $0.24 \pm 0.03$ eq. $\mathrm{Ca}^{2+}$ per molecule (see the ESI, Fig. S5 and S6a $\dagger$ ). This corresponds to roughly 0.03 eq. $\mathrm{Ca}^{2+} / \mathrm{COOH}$ and is within the experimental error consistent with the observed coil-to-helix transition at $\mathrm{Ca}^{2+}$ levels of 0.06 eq. $\mathrm{Ca}^{2+} / \mathrm{COOH}$. These results can be rationalized by postulating a dynamic calcium ion binding to the peptide. The rapid response to rather low $\mathrm{Ca}^{2+}$ concentration suggests a delicate balance between the two secondary structure states and confirms the easily shiftable structure equilibrium.
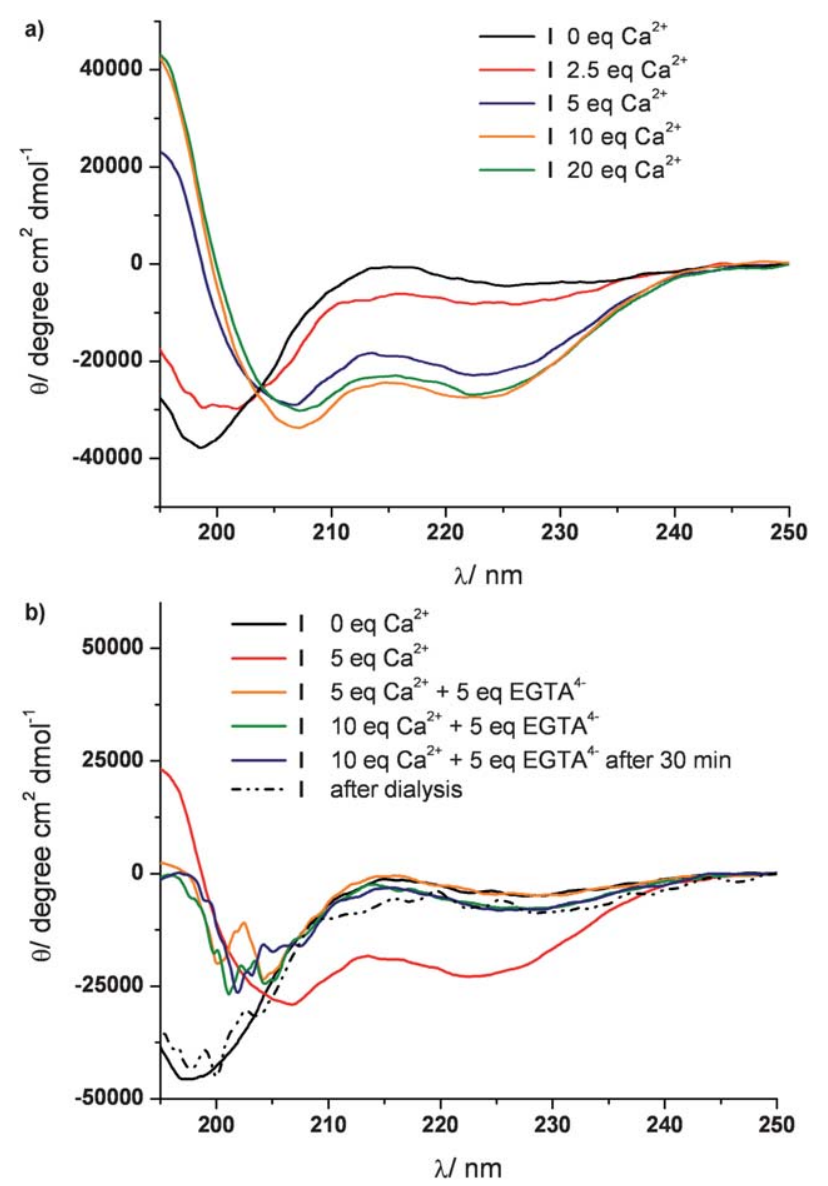

Fig. 2 (a) $\mathrm{CD}$ spectra of $\mathbf{I}\left(c=0.17 \mathrm{mg} \mathrm{mL}^{-1}(34 \mu \mathrm{M})\right.$ in Tris/HCl buffer $0.17 \mathrm{mM}, \mathrm{pH}$ 8.9) before and after addition of $\mathrm{Ca}^{2+}$. (b) Cycling of $\mathbf{I}$ (random coil without $\mathrm{Ca}^{2+}$, $\alpha$-helix after $\mathrm{Ca}^{2+}$ addition and return to a random coil structure after addition of $\mathrm{EGTA}^{4-}$ ). Owing to the content of the additive EGTA the absorption under $200 \mathrm{~nm}$ reaches cut off for the respective spectra.

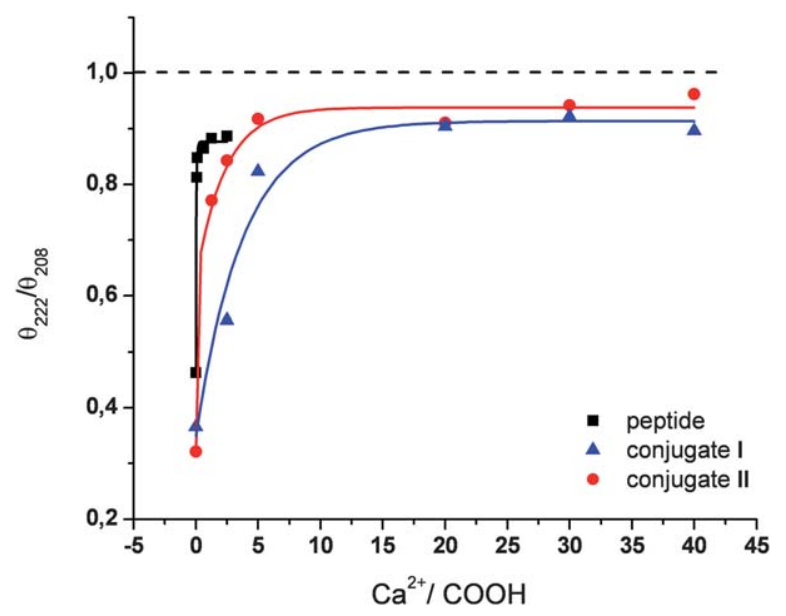

Fig. 3 Degree of helicity of peptide segments without PEO (peptide), with small (II) and larger (I) PEO-blocks in response to the calcium ion concentration. Curves were fitted using second order exponential decay ( $c=0.17 \mathrm{mg} \mathrm{mL}^{-1}$ in Tris/HCl buffer $0.17 \mathrm{~mm}, \mathrm{pH} 8.9$ ). 


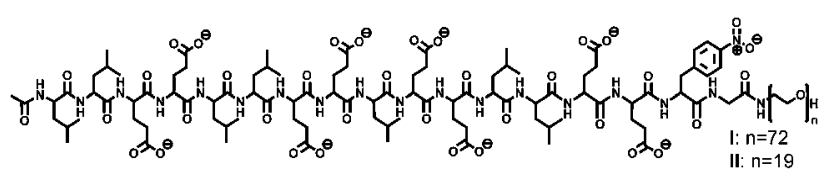

To study the influence of poly(ethylene oxide) (PEO) conjugation on the calcium induced coil-to-helix transition, two bioconjugates (I and II) were synthesized. Automated solid-phase-supported synthesis enables direct access toward the PEO-peptide conjugates with PEO-blocks of $M_{\mathrm{n}} \approx 3200 \mathrm{~g} \mathrm{~mol}^{-1}$ (I) and $850 \mathrm{~g} \mathrm{~mol}^{-1}$ (II). Standard Fastmoc coupling was applied, using an inverse conjugation strategy on a PAP resin (PEO-attached polystyrene resin). ${ }^{17}$ The fully deprotected conjugates were liberated from the support and MALDI-TOF mass spectrometry, ${ }^{1} \mathrm{H}$ NMR and FT-IR spectroscopy confirmed the chemical structures ( $c f$. the ESI $\dagger$ ).

The bioconjugate I was readily soluble in $0.17 \mathrm{~mm}$ Tris/ $\mathrm{HCl}$ buffer at $\mathrm{pH}$ 8.9. Similarly to the behaviour of the non-conjugated peptide, prior to calcium addition $\mathbf{I}$ adopts a statistical coil conformation (Fig. 2a). The coil-to-helix transition was induced by addition of different equivalents of calcium chloride. As evident from CD spectroscopy, up to 5 eq. $\mathrm{Ca}^{2+} / \mathrm{COOH}$ were required to efficiently switch the secondary structure of the peptide segment from coil to an $\alpha$-helix (Fig. 2a). The calcium ion binding capacity for the bioconjugate $\mathbf{I}$ was determined to be $0.21 \pm 0.02$ eq. $\mathrm{Ca}^{2+}$ per molecule ( $c f$. the ESI, Fig. S5 and S6c $\dagger$ ). This is consistent with the value of the non-conjugated peptide, within the experimental error and indicates that binding capacity is independent of PEO conjugation. Indeed, the increased amount of $\mathrm{Ca}^{2+}$ required to induce peptide structure transition in the bioconjugate is obvious. However, the need for a stronger trigger could be expected, considering that the PEO-coil potentially disturbs the formation of the ordered $\alpha$-helix additionally via molecular stress effects. The increased stability of the random coil structure of the peptide upon PEO conjugation is confirmed by comparing the CD spectra of the peptide with that of $\mathbf{I}$ (both $\mathrm{Ca}^{2+}$-free). The molar ellipticity of the negative Cotton effect at $198 \mathrm{~nm}$ is twice as intense for I compared to the peptide (cf. Fig. 2a and S4†). Interestingly, the effective stimulation of the peptide secondary structure transition appears to be specific for calcium ions, as addition of the same molar equivalents of barium chloride or magnesium chloride could not induce a coil-to-helix transition ( $c f$. the ESI, Fig. $\mathrm{S} 7 \dagger$ ).

To prove the reversibility of the coil-to-helix transition a strong competitive $\mathrm{Ca}^{2+}$-binder was added to lower the level of effective concentration of non-complexed calcium ions. The sodium salt of ethylene glycol tetraacetic acid (EGTA) was added to the solution of I with 5 eq. $\mathrm{Ca}^{2+} / \mathrm{COOH}$ and $\mathrm{CD}$ spectroscopy showed an immediate decrease in the molar ellipticities at $222 \mathrm{~nm}$ and $208 \mathrm{~nm}$ (Fig. 2b, orange trace). This is indicative of a rapid conformational change from $\alpha$-helix to a random coil structure, as the typical negative Cotton effects at $222 \mathrm{~nm}$ and $208 \mathrm{~nm}$ disappear. It is important to note that addition of EGTA leads to non-quantitative CD spectra below $\sim 200 \mathrm{~nm}$, owing to strong absorption of EGTA in this spectral region. However, the molar ellipticities observed above $200 \mathrm{~nm}$ clearly correspond to a random coil peptide structure not to an $\alpha$-helix conformation (Fig. 2b, black trace). Further addition of $\mathrm{Ca}^{2+}$ resulted in only a minor increase in $\theta_{222 \mathrm{~nm}}$ and hence did not directly induce $\alpha$-helix formation. The overload of salt probably disturbs the fragile balance of stabilizing and destabilizing effects in the peptide segment of the bioconjugate. However, the system could be successfully brought back to its starting point, using dialysis to remove the regulators $\left(\mathrm{Ca}^{2+} \times\right.$ EGTA).
A second bioconjugate II with the identical peptide sequence but a shorter PEO-block $\left(M_{\mathrm{n}} \approx 850 \mathrm{~g} \mathrm{~mol}^{-1}\right)$ was synthesized to determine the influence of the molecular weight of the conjugated PEO chain on the coil-to-helix transition ( $c f$. the ESI $\dagger$ ). II was well soluble in Tris/ $\mathrm{HCl}$ buffer at $\mathrm{pH} 8.9$ and adopts without calcium ions a statistical coil as shown by CD spectroscopy ( $c f$. the ESI, Fig. S8†). In contrast to conjugate I a coil-to-helix transition of the peptide segment could already be observed with 1.25 eq. $\mathrm{Ca}^{2+}$ per carboxylic acid side chain. The calcium ion binding capacity of II was estimated to be $0.30 \pm 0.03$ eq. $\mathrm{Ca}^{2+}$ per molecule (Fig. S6b广). Practically the $\mathrm{Ca}^{2+}$ ion capacity of II is rather similar to that of the peptide. The slight difference in binding capacity could be attributed to a relative error of the experiment due to interactions of the conjugates with the electrode membrane ( $c f$. Fig. S5 $\dagger$ ). As for I the calcium binding ability of the peptide segment is not altered upon PEO conjugation. In contrast to the peptide a higher amount of calcium ions is needed to effectively stimulate the coil to $\alpha$-helix transition in II. However, a clear dependence of the required $\mathrm{Ca}^{2+}$ levels on the length of the PEO-block is obvious. Where the unmodified peptide requires 0.06 eq. $\mathrm{Ca}^{2+} / \mathrm{COOH}$, II with $\mathrm{PEO}_{850}$ requires 1.25 eq. and I with $\mathrm{PEO}_{3200}$ needs 5 eq. to show a transition in the peptide secondary structure. As for the conjugate I the coil-to-helix transition of II proved to be reversible upon addition of EGTA ( $c f$. the ESI, Fig. S9†).

These findings are in good agreement with the aforementioned assumptions that the conjugation of PEO stabilizes the peptide segment in a random coil structure. Apparently, with increasing molecular weight of the PEO-block, this effect gets more pronounced. Our observations are consistent with observations in $\mathrm{pH}$ responsive bioconjugates. Klok and co-workers described the $\mathrm{pH}$ dependency of the folding of coiled-coil forming PEO-peptide conjugates and compared two different PEO molecular weights. ${ }^{18}$ Interestingly, the increase in PEO chain length resulted in a decrease in both the $\mathrm{pH}$ responsiveness of the helix content and the overall coiled-coil formation.

In summary, the present study describes a de novo designed peptide and corresponding poly(ethylene oxide)-peptide conjugates, which exhibit a calcium ion sensitive transition in secondary structure from a random coil to $\alpha$-helix. The transition occurs independently in the non-conjugated or the conjugated peptide, is fully reversible in nature, and can be regulated by the control of calcium ion levels via additional competitive binders. The influence of the length of the poly (ethylene oxide)-blocks (PEO) on the bioconjugates was investigated, showing that the PEO does not contribute to the overall $\mathrm{Ca}^{2+}$ binding capacity of the bioconjugates. However, the longer the PEO-block the more intense stimuli are required as indicated by an increased level of $\mathrm{Ca}^{2+}$ necessary to stimulate the coil-to-helix transition. The study revealed that an $\alpha$-helical peptide structure element in peptidepolymer conjugates can be controlled by soft stimuli. However, careful balancing of stabilizing and destabilizing effects in the peptide is required to realize rapid responsiveness, and contributions of PEO to stabilize certain peptide secondary structures are polymer length dependent and not neglectable.

\section{Acknowledgements}

The work was supported by the Humblodt-Universität zu Berlin, and DFG (Emmy Noether BO1762/2). We thank Helmut Cölfen for helpful discussions. 


\section{Notes and references}

1 H. G. Börner, Macromol. Rapid Commun., 2011, 32, 115; I. W. Hamley, Angew. Chem., Int. Ed., 2003, 42, 1692; I. W. Hamley, Angew. Chem., Int. Ed., 2007, 46, 8128; J. C. M. van Hest and D. A. Tirrell, Chem. Commun., 2001, 1897; D. Lowik and J. C. M. van Hest, Chem. Soc. Rev., 2004, 33, 234; L. Hartmann and H. G. Börner, Adv. Mater., 2009, 21, 3425; H. M. Konig and A. F. M. Kilbinger, Angew. Chem., Int. Ed., 2007, 46, 8334; H. A. Klok, J. Polym. Sci., Part A: Polym. Chem., 2005, 43, 1.

2 H. G. Börner and H. Schlaad, Soft Matter, 2007, 3, 394.

3 M. Sarikaya, C. Tamerler, A. K. Y. Jen, K. Schulten and F. Baneyx, Nat. Mater., 2003, 2, 577.

4 H. G. Börner, Prog. Polym. Sci., 2009, 34, 811.

5 L. A. Canalle, D. Lowik and J. C. M. van Hest, Chem. Soc. Rev., 2010, 39, 329.

6 R. Sigel, M. Losik and H. Schlaad, Langmuir, 2007, 23, 7196; J. M. Smeenk, M. B. J. Otten, J. Thies, D. A. Tirrell, H. G. Stunnenberg and J. C. M. van Hest, Angew. Chem., Int. Ed., 2005, 44, 1968; J. Couet, J. D. J. S. Samuel, A. Kopyshev, S. Santer and M. Biesalski, Angew. Chem., Int. Ed., 2005, 44, 3297; I. W. Hamley, A. Ansari, V. Castelletto, H. Nuhn, A. Rosler and H. A. Klok, Biomacromolecules, 2005, 6, 1310; S. Lecommandoux, M. F. Achard, J. F. Langenwalter and H. A. Klok, Macromolecules, 2001, 34, 9100.

7 D. M. Vriezema, P. M. L. Garcia, N. S. Oltra, N. S. Hatzakis, S. M. Kuiper, R. J. M. Nolte, A. E. Rowan and J. C. M. van Hest, Angew. Chem., Int. Ed., 2007, 46, 7378; E. Jahnke, I. Lieberwirth, N. Severin, J. P. Rabe and H. Frauenrath, Angew. Chem., Int. Ed., 2006, 45, 5383; A. K. H. Hirsch, F. Diederich, M. Antonietti and H. G. Börner, Soft Matter, 2010, 6, 88; I. Diez, H. Hahn, O. Ikkala, H. G. Börner and R. H. A. Ras, Soft Matter, 2010, 6, 3160; S. Kessel, A. Thomas and H. G. Börner, Angew. Chem., Int. Ed., 2007, 46, 9023; X. L. Li, J. Haley, H. Schlaad, R. Ju and Y. Geng, Soft Matter, 2010, 6, 2037; K. L. Christman, E. Schopf, R. M. Broyer, R. C. Li, Y. Chen and H. D. Maynard, J. Am.
Chem. Soc., 2009, 131, 521; R. S. Farmer, L. M. Argust, J. D. Sharp and K. L. Kiick, Macromolecules, 2006, 39, 162.

8 H. Kukula, H. Schlaad, M. Antonietti and S. Forster, J. Am. Chem. Soc., 2002, 124, 1658.

9 H. G. Börner, H. Kühnle and J. Hentschel, J. Polym. Sci., Part A: Polym. Chem., 2010, 48, 1.

10 J. Hentschel, E. Krause and H. G. Börner, J. Am. Chem. Soc., 2006, 128, 7722; H. Kühnle and H. G. Börner, Angew. Chem., Int. Ed., 2009, 48, 6431; R. I. Kühnle and H. G. Börner, Angew. Chem., Int. Ed., 2011, 50, 4499; J. Hentschel and H. G. Börner, J. Am. Chem. Soc., 2006, 128, 14142.

11 T. J. Deming, Soft Matter, 2005, 1, 28; J. Babin, J. RodriguezHernandez, S. Lecommandoux, H. A. Klok and M. F. Achard, Faraday Discuss., 2005, 128, 179; H. Schlaad, Peptide Hybrid Polymers, 2006, 202, 53; T. J. Deming, Prog. Polym. Sci., 2007, 32, 858.

$12 \mathrm{~T}$. $\mathrm{Xu}$ and J. Shu, Soft Matter, 2010, 6, 212; M. Pechar, P. Kopeckova, L. Joss and J. Kopecek, Macromol. Biosci., 2002, 2, 199; G. W. M. Vandermeulen, D. Hinderberger, H. Xu, S. S. Sheiko, G. Jeschke and H. A. Klok, ChemPhysChem, 2004, 5, 488; G. W. M. Vandermeulen, C. Tziatzios, R. Duncan and H. A. Klok, Macromolecules, 2005, 38, 761; J. Kopecek and J. Y. Yang, Acta Biomater., 2009, 5, 805.

13 K. Pagel and B. Koksch, Curr. Opin. Chem. Biol., 2008, 12, 730.

14 X. Q. Li, K. Suzuki, K. Kanaori, K. Tajima, A. Kashiwada, H. Hiroaki, D. Kohda and T. Tanaka, Protein Sci., 2000, 9, 1327; K. Suzuki, H. Hiroaki, D. Kohda, H. Nakamura and T. Tanaka, $J$. Am. Chem. Soc., 1998, 120, 13008; Q. Y. Dai, M. Prorok and F. J. Castellino, J. Mol. Biol., 2004, 336, 731.

15 F. Crick, Acta Crystallogr., 1953, 6, 689; C. Cohen and D. A. D. Parry, Proteins, 1990, 7, 1.

16 D. Gebauer, H. Cölfen, A. Verch and M. Antonietti, Adv. Mater., 2009, 21, 435.

17 D. Eckhardt, M. Groenewolt, E. Krause and H. G. Börner, Chem. Commun., 2005, 2814.

18 G. W. M. Vandermeulen, C. Tziatzios and H. A. Klok, Macromolecules, 2003, 36, 4107. 